\title{
The condition of recognition: Gothic intimations in Andrew McGahan's The White Earth
}

\author{
Stephanie Green \\ stephanie.green@griffith.edu.au
}

\begin{abstract}
This article discusses the evocation of the Gothic as a narrative interrogation of the intersections between place, identity and power in Andrew McGahan's The White Earth (2004). The novel deploys common techniques of Gothic literary fiction to create a sense of disassociation from the grip of a European colonial sensibility. It achieves this in various ways, including by representing its central architectural figure of colonial dominance, Kuran House, as an emblem of aristocratic pastoral decline, then by invoking intimations of an ancient supernatural presence which intercedes in the linear descent of colonial possession and, ultimately, by providing a rational explanation for the novel's events. The White Earth further demonstrates the inherently adaptive qualities of Gothic narrative technique as a means of confronting the limits to white belonging in post-colonial Australia by referencing a key historical moment, the 1992 Mabo judgment, which rejected the concept of terra nullius and recognised native title under Australian common law. At once discursive and performative, the sustained way in which the work employs the tropic power of Gothic anxiety serves to reveal the uncertain terms in which its characters negotiate what it means to be Australian, more than 200 years after colonial invasion.
\end{abstract}

Andrew McGahan's fictional interrogation of racial, spatial and cultural politics in The White Earth (2004) demonstrates the inherently adaptive qualities of Gothic narrative technique as a means of confronting the limits to white belonging in post-colonial Australia. McGahan's novel has attracted interest from readers and critics for its representation of the deeply unresolved nationalist discourse surrounding ownership and occupation of country, its engagement with Australian public history and its unflinching yet sympathetic portrait of the self-made autocrat, John McIvor. The novel references a key historical moment, the 1992 Mabo judgment, which rejected the concept of terra nullius and recognised native title under Australian common law. With its bleak tenor and intimations of devastation, McGahan's finest novel is at once discursive and performative, didactic and creatively compelling. The sustained way in which the work employs the tropic power of Gothic anxiety serves to reveal the uncertain terms in which its 
characters negotiate what it means to be Australian, more than 200 years after colonial invasion.

The repertoire of narrative devices associated with Gothic literature in the Western tradition can be traced to the emergence of related literary themes during the mid- to late eighteenth-century boom in popular genre fiction. The genre has been used variously to comment upon the impositions of authority in the Romanticist tradition, and to reinvigorate a sense of cultural identity, bringing narrative liberty to victims, and destruction or banishment to tyrants, and infusing fiction with new possibilities for reader excitation (Castle 2005; Gamer 2000). A familiar array of motifs - such as the spectacle of the decaying fortress castle, visionary symptoms of social disease, compulsive desire, exaggerated force, and the appropriation or exploitation of young or vulnerable individuals - has been widely and variously used in popular text and screen narrative both for entertainment and as a vehicle for comment upon tyranny, inequality and discrimination, from Walpole's (2001) originary Gothic novella Castle of Otranto (1764) to the Kuzui/Whedon film Buffy the Vampire Slayer (1992).

Among the many ways in which the Gothic serves as a paradigm for narrative inquiry is as a mechanism for fictional interrogations of the intersections between place, identity and power. In The White Earth, McGahan recruits many recognisable tropes of the Western Gothic narrative tradition, transporting them to a dark Australian pastoral setting as a way of critiquing the devastating impact of colonialism. The distortions of Gothic excess are not merely used here as a backdrop for the haunted adventures of a young hero, nor even to evoke an Australian literary tradition in which stories of exploitation, entrapment and isolation are endemic. Rather, the evocation of the Gothic in The White Earth serves to create a point of narrative rupture from the grip of a colonial sensibility. It achieves this, first, through the presage of an ancient supernatural presence that intercedes in the linear descent of colonial possession and, second, by invoking a rational explanation for the intercession.

A work of social critique, the novel strives to reposition the problematics of European cultural inheritance through a reorientated story arc of loss, displacement, quest and disavowal in which 'white' ownership of country is troubled by hauntings, hallucinations and shadowy presences. The McIvors have wrested the land from the Whites, 'a famous pastoral dynasty' (McGahan 2004: 23) who built Kuran House, but these newer protagonists are just as 'white' as their precursors and are equally unable to maintain a hold on stolen gains. The land itself seems to turn against them. The faded traces of European pastoral romanticism are overtaken by an apprehension of ancient spirit beings and the visceral irruption of fire. The concluding explanation for the strange impressions and events finally renders the legacy of colonialism as both destructive and passé.

One of the strengths of The White Earth is the mounting pathos of the narrative viewpoint. The story is told in varying measures through the eyes of the young William McIvor, whose bland interiority provides an effective mechanism for the theatrical confrontations of the story as he is drawn towards the 'darker country' occupied by Kuran Station (McGahan 2004: 82). While the novel takes the form of a bildungsroman in which William learns about the land and its history, to some extent this is a deliberate misdirection. Ultimately, there is nothing for the naive boy to learn or discover, except recognition of the horror of colonisation that has 
ruptured the continuum between past and present for the original people of Kuran Plains. In this sense, William can be regarded as a typical Gothic subject: trapped, ignorant, vulnerable, searching: one who reveals 'a lack in the structure' of European post-Enlightenment thinking (Mishra 1994: 117). Gradually, his boredom, curiosity and inchoate sense of guilt lead him compulsively through the Gothic maze of his Great-Uncle John McIvor's Kuran Station, with its faltering grand mansion, towards an abyss of incomprehension:

[B]eneath the swaying tree a hole opened at the base of the cliff, and down there nothing moved. At the brink, William aimed the flashlight, and they peered in. White bone shone in the beam.

'William,' the old man moaned, clutching. 'William.'

But William didn't answer. The rank smell of rotting had returned, as if the cave was filled with it, even though he knew that the bones were dry as the dust (2004: 363).

As readers, we follow William's early fearful adventures after he is brought to Kuran Station, while he explores the property, from its crumbling nineteenth century simulacrum of an English Great House to the broken White family church with its private graveyard now overtaken by vandalism and resurgent nature (2004: 65-8). Frightened, the boy wonders would 'everything on his uncle's property be the same, defaced and decayed and torn apart by the slow creep of branches and roots? If so, then what was the point of exploring any of it?' (2004: 67). But the point of William's relationship with the station is evident. As with so many works which allude to the Gothic tradition, at the heart of the story is the question of inherited possession. In this context, this question must concern how stolen property can be passed on to future generations.

Interwoven through William's spooky encounters with the dark corners of Kuran Station is the story of John McIvor's determined campaign to gain possession of the property throughout his long and bitter life. Although conveyed from William's perspective, the readerly stance of the authorial narration reminds us that this work is at once story and discourse: a double-layered pedagogical account that lays out the arguments for the reader while William struggles to make sense of what his Great-Uncle and later his activist Aunt Ruth each try to make him learn.

Depicted as an enterprising new-money upstart, McIvor's lifelong ambition has been to possess Kuran Station, taught by his father, Daniel McIvor, to regard the place as his birthright. Father and son attempt to fashion an authentic family lineage on the principle of acquired knowledge of country:

He tells William, 'buying this place was never about money'.

'What was it about then?'

His uncle spread his arms to the surrounding hills.

'It was about everything I've been saying to you. About knowing where you belong and taking responsibility for that place. This is where I belong. It's where

I was raised. I was taught all about it by my father, and he spent most of his life here too. But you now ... You can still learn, if there's someone to teach you.' (2004: 109)

As the story unfolds, however, the inherent flaw in McIvor's thinking becomes evident as a gap in recognition: a failure to identify the prior claims of the ancient 
people who had known and lived with the land on their own terms, long before the pastoralists came to their country. Displaced, wounded, lonely and in awe of his determined great-uncle, William serves as witness to the conflict of ideas which the novel directly addresses. Ultimately, he risks his life to fulfil his great-uncle's misguided fantasy of a spiritual connection with the land.

The White Earth begins with the illusory spectacle of ultimate destruction, an apparent 'mushroom cloud' above the Queensland rural horizon from the tractor fire that kills William's father. The eight-year-old boy observes the smoke as if detached from his surroundings - signaling his position of ambivalence and disassociation from time and place:

$[\mathrm{H}] \mathrm{e}$ looked out from the back verandah and saw, huge in the sky, the mushroom cloud of a nuclear explosion. He stared at it, wondering. The thunderhead was dirty black, streaked with billows of grey. It rolled and boiled as it climbed into the clear blue day, casting a vast shadow upon the hills beyond. But there was no sound, no rumble of an explosion. Hot silence lay across the wheat fields, and the air was perfectly still. (2004: 1)

Gelder and Salzman (2009) interpret this scene as an apocalyptic moment that holds the resonance of a much earlier destructive act in the name of the British Empire. As the disaster uproots William from the poor farm he calls home, The White Earth 'folds its Gothic visions and fantasies into a position on rural settlement that makes its connection to contemporary Australian political realities crystal clear' (2009: 24). The novel thus sets out to show the ways in which the shock wave of white European invasion and land appropriation that began in the late seventeenth century has led to successive waves of disaster and despair - including for the perpetrators - through a failure of recognition.

The tractor fire disaster has a direct impact on young William's position in the lineage of settler inheritance. William and his ineffectual mother are rescued by his father's rich great-uncle, whose sense of obligation in helping them seems uncertain. John McIvor's arrival at the farm after his nephew's death casts silence on the small gathering of mourners. McGahan introduces McIvor into the narrative as a meagre spectre, arriving after the funeral is over: when 'evening had turned into full night there came a final visitor, an old man who walked with a limp. He stood in the doorway to the kitchen, tall and grim' (2004: 3). The old man here comes to claim his last male descendant, and - he hopes - the beginning of a new patrilineal descent of 'white' countrymen. As the story unfolds, it becomes evident that the death of William's father is a foreshadowing of the culminating conflagration of the novel, in which McIvor's claim of a new white indigenous heritage is symbolically destroyed by fire. Indeed, as Nikro (2014: 10) remarks, in The White Earth 'history itself' is on fire'.

The new native title legislation, discussed by various players in the novel, challenges much more than McIvor's legacy. It is McIvor's daughter Ruth who raises the possibility that traditional ownership of the property could be asserted by the surviving descendants of the people of the Kuran Plains. Dolin (2014: 8) observes that McGahan's novel provides a narrative context for the 'reactions of the pastoral lobby groups and conservative politicians to the altered landscape of property law by imagining the mental and emotional structures of possession'. The twists in the plot of McIvor's acquisition of Kuran Station bring into focus the class tensions 
between the pastoralist gentry and worker settlers. We gradually learn that his father, Daniel, was a former Queensland Native Mounted Police (QMP) officer before becoming the Kuran station manager, who is never able to shake off the shadow over his name. After abandoning the struggle for acceptance by the local landed aristocracy - in particular, the White family — John McIvor has amassed a fortune and gradually gained ownership of Kuran Station through a series of strategic land acquisitions. But his attempt to assert a legacy of his own through a new male line of possession is now compromised by the threat of an Aboriginal land rights claim. To his last moment, however, McIvor holds his grip on the possession of the station that has taken him so many decades to acquire.

The distortions of authority, ownership and inheritance explored in The White Earth are richly reflective of Gothic fiction's traditional deployment of looming architectural and landscape tropes: lonely haunted houses, terrifying mountains, bottomless canyons, mysterious noises and uncertain visions. The spectacle of $\mathrm{Ku}$ ran House itself is one of the central motifs of the work - perhaps the strongest example of McGahan's deliberate use of Gothic technique to alert the reader to contradictions and instabilities in the workings of power. When William first sees Kuran House as 'a vertigo of stone' (McGahan 2004: 17), with its stately wings embracing a circular drive, 'his first amazed thought was of palaces and manors in somewhere like England, the stately homes of princes and dukes' (2004: 15). As he stares more closely at the edifice, William realises that the grandeur is no more than a first impression. The house is long past its prime, the garden has become 'a wilderness of weeds' (2004: 15) and the roof is starting to collapse:

The line of it sagged towards the middle, and dozens of tiles were cracked or sliding out of place. The gutters hung loose from the eaves, and below them, the high walls were draped in sullen vines and ivy. The upper verandah was ruinous, and within the shadow of the awning William could glimpse secondstorey windows that were shuttered or smashed. The lower terrace was littered with junk — boxes, drums, a roll of wire, a dismantled bicycle — and the front steps were cracked and sunken. (2004: 16)

The fragile hold of colonial culture on the ancient Kuran country is thus epitomised by the station's grand mansion. The house encapsulates the decayed European legacy of the landed colonial elite and the destructive stamp of occupation. Built long ago by the Whites as a haughty reflection of British Romanticist pastoral ideals, Kuran House has become a decaying pile, riddled with creaky floorboards, dark corners and even darker secrets, which William is warned has become unsafe for children to explore. On his arrival at the property, McIvor's fierce housekeeper tells William, 'You stay off those upstairs verandahs. They're not safe. You stay away from the upstairs altogether. It's no place for games' (McGahan 2004: 19).

McGahan's use of Gothic technique in The White Earth has been identified by several literary critics. Potter (2006: 179), for example, records the way in which the Great House at the centre of the story is presented as 'a talisman of the past', which contains 'something hidden and horrible'. The allusions to locked rooms containing terrifying reminders is further evidence that the account of John McIvor's heroic enterprise, the embodied fulfilment of his will to power, contains within it a disturbing, hidden truth. 
The house itself has become a 'white ruin' (Potter 2006: 179), occupied by an unrelenting tyrant whose leadership of the local Australian Independence League is intended as a further thrust to shore up his control. Kuran House is thus a signifier of occupation and ownership, in which the novel locates and unsettles linear historical narratives of modern progress and the romance of an Australian pioneer history shown to be in decline. Its walls feature blackened landscape paintings, which loom out of the interior darkness almost like hallucinations. As William observes:

The horses bore ghostly riders dressed in faded red coats. One of the men held a horn to his mouth. Painted fragments of dogs swarmed. And in the background were green patches of countryside, rolling hills and hedges, and something that looked like the ruins of a castle. (McGahan 2004: 46)

This grime-covered image of an aristocratic pastime is accompanied by the portrait of a colonial-era Darling Downs, with paddocks occupied by white sheep, while in one corner are 'Black men, looking on from the shadows, their expressions impossible to read. Hostile? Fearful?' (2004: 46). Now damaged irreparably, the wall paintings are just one of the many symptoms of postcolonial collapse. They are also linked with the novel's sustained critique of landscape as spectacle, pointing towards the narrative denouement through spatial engagement, as William is drawn out of the relative safety of the house in search of the dream embrace of the spirit country. Adopting a key characteristic of the postcolonial Gothic mode, the narrative perspective is repositioned from that of overview, available to abstraction, to one that is grounded, mapped, integral to place and its story (Kulperger 2009: 107).

During his explorations of the place, in spite of the warnings to confine himself to the ground floor, William notices that the house has 'a dank odour to it ... an underlay of rotting wood' (2004: 17), which further intensifies the impression of imminent collapse. As the story develops, the symbolism of McIvor's precarious occupation is reinforced by the impression of risk, instability and decline. At one point, we learn that the local doctor refuses to go upstairs to see John McIvor because the floorboards are so precarious. 'So why does he stay up there?' William's mother wonders (2004: 46), and it is a question that reverberates throughout the novel. As the weeks pass, the ordinariness of William's old daily life gives way to isolation and infection, further compounding the atmosphere of encroaching decline. Neglected by his addled mother, ill from the ear infection caused by a blow from his mother's hand, he is kept away from school:

'Glandular fever,' William repeated, testing the words. He understood that none of this was quite the truth. But on the other hand, why had he felt so dizzy? And what was he supposed to do for the rest of the year, if he wouldn't be at school? (2004: 46)

The appropriation of the 'boy with McIvor blood in his veins' (2004: 109) as the heir to Kuran Station reflects another dominant theme of the Gothic tradition: that of exploited youth. McIvor has another child, his alienated daughter Ruth, whom he once thought as 'good as any boy' (2004: 196). But Ruth rejects her father after he fails to protect her from a sexual assault and sends her away to boarding school (2004: 222-4). Her function in the story is to provide a counter-discourse to her father's settler-worker account of white indigeneity. Now a Brisbane lawyer, she 
supports the Native Title Bill and wants the court to acknowledge 'all that my father would like to forget' (2004: 283). Somewhat bitterly, Ruth tries to explain the issues to William, as she sees them from an ethical and legislative perspective. Caught up in his great-uncle's account of his relationship with Kuran, however, the boy is confused by her arguments. Gradually, as his fever rises, his hold on reality becomes fluid:

Everywhere he looked there was haze and smoke, vague shifting shapes that could have been anything. Towns that became farms that became empty grassland set on fire. Nothing was solid, not the land, and even less so its history. He had been told so many stories — but which ones was he to believe? (2004: 285)

Ill, ignorant and trapped by his mother's dependency on prescription medications, the negligence of the local doctor, and his great-uncle's desperate compulsion to claim him as an heir, William appears to be positioned as the central victim of the tale. For Nikro, the boy is portrayed as the figurative meeting point between the inscription of white power and the disorientation of historical recognition. His diseased ear produces 'a relational pitch of ethical resonance' that 'resides not so much in the possessive register of William's throbbing ear, not in his disease, not in terms of his numbing wound. It rather resides in how a White appropriation of wounding is situated as a pattern of exchange with those in whose midst William moves' (Nikro 2014: 5).

The white-orientated boundaries of this 'pattern of exchange' begin to blur as, increasingly, William begins to sense strange presences - apparent visitations from the ancient spirits of the land. His wanderings extend to the edges of the property with his great-uncle as a guide and interpreter of the land's secrets. McIvor's passion for rural autonomy has led him to establish a nationalist organisation, the protofascist Australian Independence League. One night, the League's members come together at a rock-encircled arena in a remote part of Kuran Station to plan their campaign against the forthcoming native title legislation. McIvor tells William why he has chosen this place to hold the meeting:

The Aborigines used to mark out rings, away in the bush, in places that were special to them. Powerful places. They were sacred. And I think this is one of them. You wait until you're up here at night, with a big fire burning ... something is present on this hill. Something comes alive. (2004: 179)

The recognition of the pre-existence of Aboriginal cultural brings with it a threat, however. For McIvor, the appropriation of the site is the necessary assertion of authentic and personal belonging to country. He regards it partly as a form of 'respect' for the original owners, but also as a form of protest. 'This land talks to me. It doesn't care what colour I am, all that matters is that I'm here. And I understand what it says, just as well as anyone before me, black or white' (2004: 181). As the narrative moves towards its climax, however, McIvor's 'white' magic proves both illusory and harmful: it is an expression of a lack of care or respect for the interests of others. 'Independence. That's the key word,' John McIvor tells his grand-nephew (2004: 127). He fears that his ownership of the property will be under threat from the native title legislation, and that the government would try to force him to reveal the secret story of the place. His establishment of the Australian Independence League is his attempt to 'put a stop to it' (2004: 128). 
An intimation of doubt about his great-uncle's beliefs arrives during the night of the League's meeting. William wanders away from the group into the bush, where he is confronted with 'an unreasoning fear' by the vision of a spirit being:

It was the light he'd glimpsed moving in the hills, all those months ago, from down on the plains. And it wasn't anything to do with the rally on the hilltop, or with the bonfire in the circle of stones. It was something else entirely. Something, William was certain, that trod the night even when there was no one else there ... And then the flame shifted slightly, and resolved into a shape, and finally, irrevocably, he saw. It wasn't a man carrying a fire, as he'd first thought - it was a man on fire. And yet the figure didn't scream or struggle, but stood perfectly still. William could discern arms and legs wrapped in flame, a torso that streamed silent fire. And a head, tilted calmly to one side, as if to ask a question while it burned (2004: 214-15).

By now, in the grip of an advanced neurological infection, William's vision foregrounds the impression of disorientation and terror associated with the novel's Gothic overtones. Contextualised by the rallying of the League members and McIvor's white nationalist rhetoric, the boy's condition seems suggestive of the wider conditions of modern Australia's most devastating social disease - 'a corporeal allegory', as West-Pavlov (2011: 101) expresses it, of the nation's abusive history and neglect of Indigenous communities. The integration of disease, alienation and the spectacle of the questioning figure serves to heighten the sense of strange displacement suffered by William. The vision thus becomes a metaphorical statement of his conflicted generational position as a white postcolonial subject who comes face to face with the burning figure of the oppressed and murdered Aboriginal people of the Kuran Plains. As Dolin (2014: 29) points out, the perplexed spectral figure suggests 'a return of the excluded other', while McIvor's desire for possession instantiates 'a gothic inheritance of guilt and obsession, founded on an act of violence against the original custodians'.

When William wanders away from the safety of the house on a fevered journey into the heat-filled bush, the trauma of the past is located and its specificity referenced, spatially and temporally, bringing the massacre of the traditional Kuran people into alignment with the historical moment of the Mabo native title judgment. Nikro points out, with reference to McCann, that the novel engages critically with an ontological presumption of Aboriginal loss (Nikro 2014: 3). Its allusions to aristocracy in decline, in this context, set the terms for a critical engagement with the past, and raise the possibility of a new narrative of place and possession. The debate between McIvor and his daughter, in particular, thus allows for the rhetorical strategy of racial disappearance to be overturned.

Ruth's role in the story is that of the voice of white conscience. It is Ruth who reveals the truth about Daniel McIvor's role in assisting colonial land acquisition by pushing the Aborigines out and killing them when they would not go. She later takes responsibility for William, rescuing him from abandonment and abuse after his mother and great-uncle die in the Kuran House fire. Ruth brings William from Kuran to hospital in Brisbane, where she has hope that he will recover from his illness. Entailed in the possibility of William's recovery is also the hope that he will emerge from his indoctrination into white neo-colonial settler heritage - that, through his embodied encounters with the horrors of their shared family history he 
will see and understand the wounds of the past. But The White Earth is not a story of settler recovery through a new connectedness with place, and William is not just a sick child in search of healing and acceptance who can be simply saved from the conflicted burden of land ownership. Symbolically, he remains a descendent of Daniel McIvor, the white officer who rode for seven years of brutal service with the Queensland Native Mounted Police, serving the interests of the government and the pastoralists. The point is driven home in the novel when the QMP cap that William finds and wears around the property, which seems to 'cast a glow of authority before it' (2004: 165), turns out to be Daniel McIvor's police uniform cap, which he wore during his years of removing the Kuran people from the plains. As Ruth reveals, the job of the QMP:

was to make sure that the Aborigines didn't bother the white settlers. Their orders were to 'disperse' any troublesome blacks ... [The] Native Police operated all up and down Queensland, and they went on 'dispersing' for over thirty years. It got so awful that it disturbed white people, even back then. There were complaints and inquiries. But that didn't stop the killing ... My grandfather was one of them. He slaughtered blacks for a living, and wore this hat while he was doing it. (2004: 335)

As the pitch of narrative crisis rises, William becomes an expression of the timbre of inter-generational undecidability in post-invasion Australian legal politics, the carrier of a sustained resonance between generations that is still unresolved.

McGahan's deployment of Gothic allusion is significant as a critique of postEnlightenment colonial power. The way in which the novel locates the conflict between the dominance of a conflicted white settler mentality and the spectral traces of traditional Aboriginal ownership foregrounds McGahan's underlying interrogative stance. The novel directly challenges the ideological imperative of Romantic lament, as Nikro (2014: 3) remarks, for 'the passing, the dying-out of indigenous subjects' as part of a process of aestheticisation that frames contemporary recognition of the material conditions of stolen possession. The use of the Gothic, however, serves to render this European aestheticised perspective as uncanny, invoking a resurgence of ancient voices and ancient law.

This uncanny resurgence is most fiercely represented by the fire that consumes Kuran Station and takes the lives of William's mother and John McIvor (2004: 368-70). The motif of fire recurs throughout the novel as a significant force, which McGahan employs for narrative and symbolic effect. Fire in The White Earth provides a mechanism for ambiguity and terror: it is a symbol of destruction and purification, loss and connection with the past, which 'animates the dissonant, polyphonic tenor of haunting and historical exigency woven into McGahan's novel' (Nikro 2014: 6).

Indeed, instances of the use of fire as a representational figure for destruction and renewal abound in nineteenth-century Gothic fiction: among the most archetypal of examples is perhaps Bronte's Jane Eyre. Fire in The White Earth is, of course, also transformational - both for good and for ill. The story culminates in the conflagration of Kuran House as a symbolic challenge to ideological and material dominance (2004: 368-70), at the same moment in which William is almost consumed by his hallucinatory encounter with the Bunyip. The fire renders the property ownerless (2004: 374) and McIvor intestate, leaving the way open for 
the possibility of an Aboriginal claim. This has been anticipated both by William's apprehension of ancient supernatural presence and, in historical terms, by Ruth's discovery that some of the descendants of the original Kuran people are still alive and living in the Cherbourg community. Her persistent actions in seeking an alternative to inheritance are crucial as a vehicle for the dialogical response to the discourse of white supremacy espoused by her father.

The use of the Gothic mode in The White Earth provides a carefully positioned sense of aristocracy in decline, as a way of interrogating Australian colonial practices of ruthless land acquisition and social control. William's apprehension of uncanny forces can partly be read as an emerging generational awareness of the possibility of ambivalence, uncertainty and resistance to colonial common law. Ultimately, however, William's visions are shown to be the by-product of a cholesteatoma, leading to an acute neurological condition (2004: 374). Here, McGahan uses the technique of 'explained Gothic', in which the supernatural events are given an entirely rational explanation (Williams 1995: 74) as the narrative draws to a conclusion. William's infected ear and the spread of his disease signal a profound failure of reason and comprehension in order to show how the edifice of Australian postcolonial culture remains haunted, in real terms, by its past and lack of present action. The novel concludes with a reflective epilogue conveyed from Ruth's point of view. Exhausted and injured following the fire, she reflects on the unresolved legacy of Kuran Station as she watches the orphaned William, still unconscious after his brain surgery:

She gazed down at William. Such a sad and silent child. She didn't think she had ever seen him smile. Pity bit at her, and a weight settled against her heart. Was he her responsibility now? Oh ... but she was too old. The burden couldn't fall on her. (2004: 376)

Through Ruth, the novel articulates the significance of the Mabo decision and its promise for the future of native title. Equally, her bruised ambivalence is a reminder of the ongoing public contest that surrounds the significance of the Mabo case and the need for more profound legal and social changes. The novel ends with Ruth starting to turn away from William and from the hope of transformational agency, until she recalls her father's love of his daughter and of the land itself: 'a memory came. The smell of earth, and of wheat, and the feeling of a familiar hand upon her head, rough with calluses, and so strong. All of it wasted, all of it ruined' (2004: 376). As William mutters in his sleep, she returns to the boy's bedside to wait and watch for a future in which acknowledgement and repair remain possible but uncertain.

\section{References}

Castle T. 2005. 'The Gothic novel'. In Cambridge History of English Literature, 16601780, Cambridge: Cambridge University Press.

Dolin K. 2014. 'Place and property in post-Mabo fiction by Dorothy Hewett, Alex Miller and Andrew McGahan'. JASAL 14(3): 1-12.

Gamer M. 2000. Romanticism and the Gothic: Genre, reception, and canon formation. Cambridge: Cambridge University Press. 
Gelder K. and Salzman P. 2009. After the celebration: Australian fiction 1989-2007, Melbourne: Melbourne University Press.

Kulperger S. 2009. 'Familiar ghosts: Feminists postcolonial Gothic in Canada'. In Unsettled Remains: Canadian Literature and Postcolonial Gothic, Waterloo, ON: Wilfrid Laurier University Press.

Kuzui F., Rosenman H. and Whedon J. 1992. Buffy the Vampire Slayer. Sandollar Kuzui Enterprises, Twentieth Century Fox.

McGahan A. 2004. The White Earth, Sydney: Allen \& Unwin.

Mishra V. 1994. The Gothic sublime, Albany, NY: State University of New York Press.

Nikro N.S. 2013. 'Pitching ethical resonance: Andrew McGahan's The white earth'. JASAL 13(3): 1-15.

Potter E. 2006. 'Andrew McGahan's The White Earth and the ecological poetics of memory'. Antipodes 20(2): 177-82.

Walpole H. 2001. Castle of Otranto. Ed. Michael Gamer. London: Penguin, 2001.

West-Pavlov R. 2011. 'Invasion and pathology: Australia, Mabo, McGahan and Malouf'. In Imaginary Antipodes: Essays on Contemporary Australian Literature and Culture. Heidelberg: Universitätsverlag.

Williams A. 1995. Art of darkness: A poetics of Gothic. Chicago: University of Chicago Press. 